\title{
Resisting the Siren Song: Charting a Course for Justice
}

\author{
Joe Blosser \\ High Point University
}

Edward Zlotkowski's (1995) concern over 20 years ago was that without institutionalization in the academic structures of colleges and universities, service-learning and community engagement (SLCE) might fade away or be co-opted into "still another academic specialty" (p. 129). Fortunately, many heeded his call, and SLCE has become a central and defining feature of many higher education institutions. SLCE leaders on campuses worked hard to build coalitions of stakeholders in the past decades, but many of these stakeholders were enticed to support SLCE for their own ends: Public relations offices needed human relations stories for the media, business offices needed an easy way to ensure they met the $7 \%$ minimum threshold for federal work-study students serving in the community, student life offices wanted volunteer structures in place to make it easier to sentence students to community service for disciplinary violations, advancement offices wanted to lure donors based on the institution's service commitments, admissions offices wanted to tout volunteer opportunities, and so on. As an institutionalized movement, SLCE now must find a way to live and thrive within these neoliberal incentive structures that make its continued existence on campuses possible.

SLCE lives within the dominant neoliberal structure of American colleges and universities. Simply put, the neoliberal frameworks that infuse American life today strive to monetize all human interactions, turning institutions of higher education into sites of efficiency, productivity, revenue production, and customer service. More than just restricting the range of possible ends, neoliberalism produces within people a desire to conform and promote neoliberal ends. Some scholars are optimistic that SLCE can turn the tide on neoliberalism (Orphan \& O'Meara, 2016), and others see SLCE as too wrapped up in a liberal agenda to be an adequate force for transformation (Simpson, 2014). I fall somewhere in the middle, believing that SLCE can create a powerful and transformative sub-culture through which students, faculty, and community members can create structures for justice within a neoliberal framework. But if we are not aware of the incentives driving our stakeholders, we may succumb to them. As Kliewer (2013) warns, "by maintaining a civic engagement movement that does not account for neoliberalism, we could potentially be undermining the very democratic sentiments and institutions that the movement attempts to revive" (p. 73). The future of the movement will depend on the ability of SLCE leaders to recognize and navigate the neoliberal incentives on our work, using them to further our objectives but resisting the urge to let the work be co-opted.

\section{Influence of Incentives on SLCE}

To see if my impressions of the movement were shared by other SLCE leaders, I spent the better part of my time at the North Carolina Campus Compact Pathways to Achieving Civic Engagement Conference and the Campus Compact $30^{\text {th }}$ Anniversary Conference, both taking place in Spring 2016, soliciting attendees' stories about what incentivized their stakeholders to get behind SLCE. They told stories of campus public relations offices needing a "feel good" story of service to distract from bad press at the university. They told stories about faculty who wanted heart-warming service projects for their students in order to get good course evaluations. They told stories of students wanting to change the world by starting yet another campus mentoring program - without ever consulting any of the myriad of extant campus mentoring programs. And like good improvisational actors, the SLCE professionals and partners I spoke with responded to each of these situations with a, "yes, and ..." They sought to encourage the energy, money, passion, and learning of these stakeholders but, in the process, nudge them away from their more neoliberal impulses and toward more sustainable, justice-oriented projects. Rather than promote neoliberal forms of service that depend on - and reinforce - the power gap between campus and community by emphasizing short-term, optics-oriented, results-driven service, many SLCE professionals want to push beyond "traditional" service-learning, charity models of service, and deficit-based mind- 
sets to promote service that seeks deep social transformation by upending traditional power structures (Lupton, 2011; Mitchell, 2008). Engagement in such transformational work requires a deep understanding of the neoliberal incentives that can both facilitate and undermine our journey.

To be clear, I do not think any SLCE professional has "clean hands" - no one operates outside of entrenched - and sometimes damaged - systems. Nor do I think people using or offering neoliberal incentives are of questionable moral character. I am asking the pragmatic question, "How do we use the incentives that exist to move the work of justice forward?"

I start with the incentives mentioned by community partners. While many (maybe most) community partners come alongside practitioner-scholars seeking to help students learn and to improve the services provided to the community, all community partners also have additional pressures on them, which influence the shape of their involvement with institutions of higher education. They may seek a relationship with the campus to bolster their reputations, their fundraising, or their donor relations. They may know that solid campus partnerships sometimes open the door to financial resources. And, at some colleges and universities, community partners of distinction are invited to campus events and conferences, are eligible for awards, and so on. Given that nonprofits exist amidst similar neoliberal pressures as campuses, many are structured according to a deficit-based approach that perpetuates the neoliberal power structure of have and have-nots (Kretzmann \& McKnight, 1993). Their boards are populated with philanthropists and well-meaning volunteers who see a problem in the community and want to fix it. Their desire can be to enlist students who want to volunteer to "solve" a problem. When SLCE practitioner-scholars try to engage in capacity building projects, asset-based approaches, or community-engaged research, some partners simply do not see the value or payoff. They need volunteers to sort clothes, organize the food pantry, and fix up the building. When students serve at such agencies, they may have positive experiences of feeling valued for the help they provide. Yet, they can also have experiences that reinforce their deficit mindsets, which can frustrate faculty who want to help students understand systemic social issues.

For their part, faculty tend to be driven by the incentive structures on our campuses. At $94 \%$ of schools studied by the American Association of University Professors (2016), much weight is given to student course evaluations - a nod to the power of the customer-service model of neoliberal higher education (Miller \& Seldin, 2014). More than one professor has shared with me the need to design SLCE courses matched with well-staffed community partners who communicate quickly with the students, have flexible hours, and provide students with work that makes them feel like they made a difference (e.g., mentoring a child, filling food boxes, painting, delivering food). Deficit-based service can feel good and lead to solid course evaluations; it can even fulfill major community needs. But such "traditional service-learning" only reinforces power structures (Mitchell, 2008). It can be hard to get some faculty who are concerned about their course evaluations to take a risk on a community-engaged research project for the first time or work behind the scenes building an agency's capacity. Though I have seen amazing course evaluations come out of SLCE courses in which faculty and students adopt an asset-based orientation to their partnerships and projects, these professors often put in extra hours and frequently teach upper-level courses with smaller class sizes and more invested students.

At some institutions junior faculty have been told to wait until after attaining tenure to engage in SLCE. Community-engaged research is often seen as a lesser form of research, and faculty who spend extra hours developing community partnerships are seen as lightweights or wasting their time. With the rapid rise of contingent faculty that now make up $70 \%$ of all university faculty (AAUP, 2016), it is important to understand that incentives for engaging in SLCE differ depending on the institution. At some colleges and universities contingent faculty may shy away from SLCE because it is seen as too dangerous to risk a bad set of course evaluations due to forces beyond the instructor's control (such as staff turnover that leads to chaos at the community organization). But at other institutions, contingent faculty may seek out SLCE to demonstrate to their chairs and deans how seriously they are invested in their students' learning and the institution's commitment to the community.

Though most SLCE faculty I know have a heart for the work, even the most committed faculty feel the pressure to take on projects that are easier to manage. This can lead them toward deficit-based partnerships and projects in which students are plugged into service and faculty only have to dropin from time-to-time to see how things are going. SLCE professionals who coordinate numerous SLCE experiences also know that these "plug-andplay" experiences are often easier to manage from an administrative standpoint. They demand fewer campus resources than asset-based projects, which often rely on teams of stakeholders, regular communication, and intensive relationship building. Deficit-based projects also typically result in more 
easily calculated service hours. In a communityengaged research project, for example, it can be hard to calculate how many research hours constitute community service hours versus course assignment time.

The societal shift toward a consumer model of higher education has, in some ways, given students (and their parents) substantial power to influence how SLCE looks on campus (Kreuter, 2014; Perry, 2014). Many students have a passion and longing to make a difference, to get involved. One of the pressures mentioned repeatedly by the SLCE faculty and program directors with whom I spoke was the desire of students to start something new, to be entrepreneurs, to follow their passions by creating a project. One SLCE professional attributed this to the "millennial start-up mentality." Instead of joining existing projects or long-term partnerships, students often want to pave their own trail. Our culture and our campuses emphasize being "job-makers," "leaders," and "entrepreneurs," so students often see SLCE as a place to test out their skills before they head to the job market.

There are also students who see SLCE as a way to bolster their resumes and popularity. A student once told me that, by winning service awards and being featured regularly in the campus news, she was achieving her goal of becoming known around campus - of being "college famous." While most of the students I work with are not so opportunistic about their SLCE involvement, the pressure to build resumes and job skills is high for many students. SLCE can easily become a laboratory for students who want to try new things, build their own programs, and leave their mark. These can be powerful motivators and positive traits if they are funneled in a positive right direction and are bolstered by regular reflection and solid community relationships.

\section{The Effect of Institutionalization and Certification}

With institutionalization comes the pressure to contribute to the mission of the campus as defined not by SLCE practitioner-scholars but by the neoliberal framework shaping most institutions of higher education. They may be asked by the public relations office for stories about how the campus has solved a community problem or improved the lives of community members. Stories about capacity building or relationship building often do not "sell" as well or have as vibrant a "visual appeal" because they often take years of relationship building and sustained effort in the community. Higher education institutions are also increasingly seeing the value of SLCE for student retention, alumni en- gagement, donor recruitment, and/or opportunities to feature the religious commitments of the school. These can be positive forces that more deeply embed SLCE into the cultural lifeblood of an institution, but they also come with pressure to produce de-politicized SLCE opportunities. In particular, there is pressure to avoid polarizing projects, like those involving activism, voter engagement, or community organizing around politically sensitive justice issues such as climate-change, marriage rights, or living-wage campaigns.

With the rise in national certifications, including the President's Honor Roll and the Carnegie Community Engagement Classification, campuses may see value in promoting SLCE in order to raise the institution's profile. These awards can be positive forces, but a higher education institution may also push to obtain the Carnegie Classification, for example, without developing the necessary infrastructure to produce sustainable, best-practice models of SLCE.

SLCE professionals who oversee curricular programs may feel institutional pressure to list a certain number of courses each semester, to ensure partners and projects have ongoing relationships with SLCE courses, and so on. As SLCE programs grow larger, they tend to need more logistical support to ensure campuses live up to their commitments. And if a minor or certificate program is offered, there is usually curricular pressure to offer courses on a reliable basis. These can be positive pressures, but they can also push faculty to continue teaching a course "beyond the lifespan of the project," as one professor recently remarked to me.

\section{The Pressures of Assessment Culture on SLCE}

Finally, in the list of incentives luring SLCE, I think there are pressures from the wider SLCE community. Numerous organizations and grant foundations support the work of SLCE and cultivate the spread of best practices. I have encountered two trends that trouble me related to this support: the epistemological takeover of assessment by the social sciences and the focus on student psychosocial well-being. With regard to assessment, the SLCE movement has fallen in line with the growing national assessment culture. Evaluating programs, partnerships, learning, and more can be positive; however, narrowing the framework for valid assessment to Bloom's Taxonomy or other traditional educational standards restricts our ability to value indigenous, relationship-based, non-western, and non-positivist ways of knowing. Human relationships are built on more than analytical forms 
of knowledge, and the reduction of a partnership to an assessment tool can diminish the partnership itself. Insertion of an assessment - especially one limited to positivist ways of knowing - to evaluate the quality of community partner relationships can even have a chilling effect on these relationships.

The Association of American Colleges and Universities, along with Bringing Theory to Practice, has recently promoted the idea - through publications and grant funds - that SLCE can and should have a positive influence on student psychosocial well-being. Checkoway (2011) defines psychosocial well-being, saying it "places emphasis on the conditions that enable people to flourish, rather than focusing on what is wrong with people, and tries to cure what ails them" (p. 7). It sounds like a worthy goal, but Bringing Theory To Practice interprets this to be about how service can reduce "substance abuse and depression on campus" (Swaner 2007, p. 16). The Robert Wood Johnson Foundation (1997) similarly supports the use of service to reduce substance abuse, saying campuses should require students to "undertake a certain number of hours of volunteer work to reduce their free time and to give their educational experience additional meaning" (p. 39).

Student life professionals and others who worry about student retention, substance abuse, and similar issues have different objectives in mind for service than many SLCE offices. Levine (2011) warns that "There is some risk that the default justification for civic engagement may become its psychological or developmental benefits for participants; resources will then be directed to non-controversial 'helping' and 'joining' activities, and youth engagement will become largely therapeutic" (p. 14). Student learning is quite different from student psychosocial well-being. Indeed, there are worthy civic engagement opportunities that may leave students depressed, anxious, and less sure of themselves and their place in the world - but through them students may grow, learn, and make a powerful impact on the world. Levine (2011) offers the Freedom Riders as just such an example of service that profoundly turned the world toward justice but left psychological scars on the participants.

\section{Examining Motivations for SLCE}

Quite often the incentives offered by our stakeholders urge us to travel in the direction of charity work: to hitch our wagons to easy, fun, assessable, visually-rich (for the media), and meaningful service opportunities that fit neatly into people's preconceived categories of "giver" and "recipient." But the further in this direction we travel, the harder it is for us to see the deeper injustices and policy failures that require such charity work to be done. There is most certainly a time and place for charity, for giving without question and offering help to those in need. But in our broken - in Christian terms, "sinful" - world, the pure gift, pure charity, pure love is impossible. It too often enables dependency and overlooks systemic injustice. As Reinhold Niebuhr (1979) reminds us, in such a broken world, justice is the closest thing we can obtain to true love. And the work of justice requires unearthing inequitable power structures; revealing sexism, racism, classism, and homophobia; and engaging in a struggle for genuine partnerships across communities. Many of the SLCE professionals with whom I talked at the conferences last spring want to engage in such justice work, but they also feel pressure from their stakeholders to engage in charity work to justify their SLCE programs. Charity work fits more cleanly into the neoliberal framework because it reinforces the often unspoken power inequalities between giver and recipient.

The hard part about justice work, which can (though does not always) include asset-based approaches, community-engaged research, capacity building, and policy work, is that to do it we may have to push back against the stakeholders we have spent years cultivating. Yet, we still need these stakeholders if we are to exist within higher education. It is difficult, though, to work toward justice without staking out particular moral and political positions - positions that may alienate key stakeholders. We must struggle head on with how to navigate these competing pressures. The danger I see for SLCE - having now become an institutionalized part of an increasingly neoliberal educational landscape - is that if we succumb to all these incentives, we will become nothing more than the "pressure release valve" of the academy, allowing faculty, students, and administrators to feel like we are helping "the community" as we place one bandage after another on a gushing wound.

\section{Shaping Future Pathways Toward Justice}

The future pathways of SLCE must navigate the tension between the neoliberal incentives that often support our work and the justice orientation shared by many in the field. We must become aware of and adept at navigating the incentives driving our stakeholders, but we cannot surrender to the neoliberal siren song. To be clear, this is not a moral critique of the character of individual stakeholders - the public relations staff, the advancement team, local philanthropists, eager students, or anyone else invested in charity models of service - nor do 
I intend to suggest that SLCE practitioners are of higher moral character ourselves. This is an argument about systems and structures. To paraphrase Niebuhr (1932), it is about moral people in often immoral structures.

The future of SLCE is to educate students, faculty, and community members in the ways of justice, seeding a critical consciousness within the heart of our campuses and communities. It is about taking actions such as developing more qualitative and affirming modes of assessment, seeing "students as colleagues," co-teaching with community members as paid equals, and challenging everyone to recognize the neoliberal incentives luring our work and how to use these to move in a different direction to move toward justice. I do not believe SLCE will overthrow the neoliberal frameworks that shape modern higher education, but we can be a refuge, a place to courageously explore and shape the pathways of justice that stretch out before us.

\section{References}

American Association of University Professors. (2016). Background facts on contingent faculty. Available at: http://www.aaup.org/issues/contingency/backgroundfacts

Checkoway, B. (2011). New perspectives on civic engagement and psychosocial well-being. Liberal Education, 97(2), 6-11.

Kliewer, B. W. (2013). Why the civic engagement movement cannot achieve democratic and justice aims. Michigan Journal of Community Service Learning, 19(2), 72-79.

Kretzmann, J., \& McKnight, J. (1993). Building communities from the inside out: A path toward finding and mobilizing a community's assets. Evanston, IL: Institute for Policy Research, Northwestern University.

Kreuter, N. (2014). Customer mentality. Inside HigherEd. Online. Retrieved from https://www.insidehighered. com/views/2014/02/27/essay-critiques-how-studentcustomer-idea-erodes-key-values-higher-education.

Levine, P. (2011). What do we know about civic engagement? Liberal Education, 97(2), 12-19.

Lupton, R. D. (2011). Toxic charity: How churches and charities hurt those they help (and how to reverse it). New York: HarperCollins.

Miller, J. E., \& Seldin, P. (2014). Changing practices in faculty evaluation. Academe, 100(3), 35-38.
Mitchell, T. (2008). Traditional vs. critical servicelearning: Engaging the literature to differentiate two models. Michigan Journal of Community Service Learning, 14(2), 50-65.

Niebuhr, R. (1932). Moral man and immoral society. New York: Charles Scribner's Sons.

Niebuhr, R. (1979). Interpretation of Christian ethics. New York: Seabury Press.

Perry, D. (2014). Faculty members are not cashiers. Chronicle of Higher Education. Retrieved from http://chronicle.com/article/Faculty-Members-AreNot/145363/.

Robert Wood Johnson Foundation. (1997). Be vocal, be visible, be visionary: Recommendations for college and university presidents on alcohol and other drug prevention. Princeton, NJ: Robert Wood Johnson Foundation, Fund for the Improvement of Postsecondary Education.

Simpson, J. S. (2014). Longing for justice: Higher education and democracy's agenda. Toronto: University of Toronto Press.

Swaner, L. E. (2007). Linking engaged learning, student mental health and well-being, and civic development: A review of the literature. Liberal Education, 93(1), 16-25.

Zlotkowski, E. (1995). Does service-learning have a future? Michigan Journal of Community Service Learning, 2(1), 123-133.

\section{Author}

REV. DR. JOE BLOSSER (jblosser@highpoint. edu) is the Robert G. Culp Jr. director of Service Learning and assistant professor of Religion and Philosophy at High Point University (HPU). He is the founding director of the HPU Service Learning Program and Bonner Leader Program, and he teaches courses in Business Ethics, Educational Ethics, and Modern and Contemporary Christian Theology. Dr. Blosser specializes in the ethical implications of economic theory and Christian theology. He has published articles in the Michigan Journal of Community Service Learning, Research in the History of Economic Thought and Methodology, Journal of Religious Ethics, Journal of the Society of Christian Ethics, Journal of Cultural and Religious Theory, Encounter, Homiletic, and Religious Studies Review. 